\title{
FORGING THE PAST: FACTS AND MYTHS BEHIND THE MONGOL INVASION OF MORAVIA IN 1241*
}

\author{
Tomáš Somer \\ Palacký University Olomouc \\ Olomouc, Czech Republic \\ tomas.somer@upol.cz
}

\begin{abstract}
Research objectives: There are two research objectives to this study. The first is to survey the events of the Mongol invasion of Moravia in the spring of 1241 and the second is to examine how the story changed over the following centuries. The narrative surrounding the Mongol invasion lost its grounding in fact, and different versions of the story quickly arose. In this paper, I will explain when, why and how the story evolved.

The Research materials are therefore diverse. The first part of the article is based upon $13^{\text {th }}$-century sources (charters, epistles, chronicles) of Central European origin. In the second part, later medieval chronicles as well as early modern historical treatises will be studied. These works influenced the perception (and form) of the story both at home and abroad since many of them were accessible in different languages.

The Results and novelty of the research are therefore twofold. Since the Mongol myth became the subject of $19^{\text {th }}$-century forgeries, many scholars were misled by them. As a result, the forged documents have been presented as trustworthy sources even by renowned contemporary scholars. Consequently, the description of the historical events of 1241 undergo dramatic changes. The invasion - presented at times as a catastrophe - was in reality merely the brief passage of Mongol troops through Moravian territory. Later chroniclers confused this event with the Hungarian invasion of Moravia in 1253. Soon, a fictional victory at Olomouc was invented. Later, an imaginary hero was added (Jaroslav of Sternberg) and the story transformed in the second half of the $17^{\text {th }}$ century into an account of a divine miracle, subsequently becoming a key part of the $19^{\text {th }}$ century forgeries that exaggerated the Czech glorious national past by inventing sources that had actually never existed.
\end{abstract}

Keywords: Mongol Empire, Moravia, Cumans, 1241, historiography

For citation: Somer T. Forging the Past: Facts and Myths behind the Mongol Invasion of Moravia in 1241. Zolotoordynskoe obozrenie=Golden Horde Review. 2018, vol. 6, no. 2, pp. 238-251. DOI: 10.22378/2313-6197.2018-6-2.238-251

Among contemporary historians dealing with the history of the Mongol Empire in the $13^{\text {th }}$ century, there tends to be some confusion about the details of the invasion of Central Europe by the Mongol army from 1241 to 1242. They often present different opinions on the same subject, or have utterly false information. Take for instance a simple question: Who led the Mongol troops into Poland and Silesia in 1241 and how strong was that army? The answer varies a lot - the main leaders were probably Orda and Baidar (known in the West as Peta) and perhaps Kadan (Qadan, Qaidan) as well. Sometimes even Qaidu (Kaidu) II (1236-1301) -

* This study is based on research conducted for the project Magdeburský arcibiskup, schwerinský a litomyšlský biskup, duchovní, diplomat, zakladatel a mecenáš (FPVC2017/13) granted by the Palacký University in Olomouc, Faculty of Arts from the Fond pro podporu vědecké činnosti. 
who was about five years old at that time - is mentioned (he was most probably mistaken for Kadan) $[45$, p. $12 ; 26$, p. $138 ; 23$, p. $62 ; 10$, p. $172 ; 24$, p. $70 ; 25$, p. $18 ; 6$, p. $96 ; 46$, p. $86 ; 5$, p. 218]. The strength of this army is also unclear; it is estimated to be 10,000-30,000 men (1-3 tümens) strong. There is also one marginal subject within this campaign that is almost always described incorrectly - if at all. It is the presence of the Mongol army in the territory of Moravia (which formed the eastern part of the Kingdom of Bohemia). After the victory at Legnica (Liegnitz) on 9 April 1241, the surviving Mongol troops moved onwards to join their comrades in Hungary and in doing so, they marched through Moravia. The renowned historian Peter Jackson, in an otherwise great book, wrote the following about this particular event:

"In Moravia despite a sanguine report that the fortified places escaped the devastation, the towns of Littaou, Freudenthal and Gewiczko were destroyed, while Brünn (Brno), Olmütz (Olomouc) and Uničov suffered damaging sieges" [23, p. 68].

This is in fact not true; Prof. Jackson was deceived by the $19^{\text {th }}$ century forgeries. Describing what really happened in Moravia in the spring of 1241 will be the next step.

$$
* * *
$$

Let us begin our journey on the battlefield near Legnica (Liegnitz) on 9 April 1241, where the Piast Duke Henry II the Pious was defeated and killed. The $15^{\text {th }}$ century historian Jan Dhugosz, the most important source for the description of the battle at Legnica, puts forward the information that the first rank of Henry's army was led by Boleslaus, son of the Margrave of Moravia Dipold, who also met his death on the battlefield that day ${ }^{1}$. This information has been repeated by many historians (who sometimes made additional blunders), but it is only a half-true [23, p. $62 ; 6$, p. $98 ; 25$, p. 27]. Dipold (Theobaldus) III was in fact a member of a secondary lineage of the Přemyslid dynasty (the ruling dynasty in the Kingdom of Bohemia), but he never became the Margrave of Moravia. It is plausible that after the death of the Margrave of Moravia Vladislaus Henry in 1222, he tried to seize control over Moravia, but if that was the case, he was unsuccessful. Dipold's kindred were expelled from the Kingdom of Bohemia in 1222/1223 to Poland, never to return again, and Dipold himself probably died in 1223 while defending his castle, Kouřim [11, p. 111-115, 118-122].

The goal of this detached Mongol army operating in Poland and Silesia was to make sure that no reinforcements from this region distracted the ongoing operations in Hungary. After the battle at Legnica, this goal was completely fulfilled and the Mongol army in the north had no reason to stay there anymore. Moreover, Wenceslaus I, the King of Bohemia and the father-in-law of Henry II the Pious, was only about a two days' march away with his knights [7, p. 498-499, nos. 306-307]. What happened next is unclear. The Mongol army probably rested for a while and in the meantime, the king of Bohemia and his army possibly moved back to Bohemia to secure the northern border of the kingdom. The information about some military operations near the Bohemian town of Kladsko (Glatz, today Kłodzko in Poland) on the northern border is based upon an early $14^{\text {th }}$-century Bohemian chronicler, the socalled Dalimil. Even though this chronicler is otherwise quite an unreliable source

1 “(...) id Boleslaus marchionis Morawie filius ducebat (..)”; “(...) Boleslao Dipoldi marchionis Morawie filio (...)" [22, p. 20-21]. 
for the Mongol invasion, this might actually be a true event [47, p. 313-325]. Orda and Baidar moved quickly to Hungary to join their leader Batu, who delivered a humiliating defeat to the King of Hungary Bela IV and his army near the river Sajó (Muhi) just two days after the battle of Legnica.

Unable to cross the well-protected and mountainous border with Bohemia, the Mongols moved further east and entered Moravia near Opava (Troppau) through a pass with a very appropriate name: the Moravian Gate [7, p. 201-203, no. 108]. This happened probably less than a month after the battle at Legnica. The highranking Franciscan Jordanus mentioned in one of his letters that the Mongol troops entered Moravia some time before the $9^{\text {th }}$ May [7, p. 500, no. 308]. This might actually have happened a little bit earlier, since according to reports Orda and his army arrived in the vicinity of the important Hungarian castle Trenčín (Trentschin, Trencsén) in late April. The castle itself resisted the Mongol army, but the surroundings suffered heavy damage [48, p. 14, 17]. The exact route of the Mongol army through Moravia is largely unknown. We only know that the entry point was somewhere around Opava (Troppau) and that they probably left through the Hrozenkov pass leading to Trenčín. The only real evidence of actual destruction comes from 1247 when the Margrave of Moravia (and future King of Bohemia) Přemysl Otakar granted the city of Opava some economic privileges based upon unspecified damages to the Opava region caused by the marauding Mongol troops some years earlier [7, p. 201-203, no. 108]. The Mongols did not seize any of the fortified places in Moravia and it is a plausible argument that they did not even try to, since they were in a hurry. The haste of the invaders is actually one of the very few facts we can support using the sources: Master Roger was a well-educated canon of Oradea (Großwardein, Nagyvárad, Varadinum) who was himself taken prisoner by the Mongols and unwillingly spent several months amongst them in captivity. His Miserabile Carmen with its accompanying letter is one of the most important sources about the deeds of the Mongols in the Kingdom of Hungary. At one point, he informs us that after defeating one of the Polish dukes (Henry II the Pious) and destroying Wrocław, the "King" Peta (Baidar) and his troops marched quickly through Moravia towards the "Hungarian gate"2, a pass on the border with the Kingdom of Hungary (probably the Hrozenkov pass). In doing so, according to Master Roger, the Mongols destroyed the Moravian countryside with their usual cruelty [48, p. 81, 83]. This is further supported by the Annales sancti Panthaleonis Coloniensis (composed around the time of the Mongol invasion), which mentions the incredible speed of the Mongol troops (supposedly, they marched through Moravia in just one day and night) and also the standard destruction of the land - except for the castles and other fortified places, which they left alone [1, p. 535]. Mongol troops probably visited Moravia once again in the winter of 1241/1242 when the Danube froze over in late December and they entered the western part of Hungary, eastern Austria and southern Moravia, as we learn from a letter from Vienna by an unknown Benedictine Abbot dated the $4^{\text {th }}$ of January 1242 and recorded by Matthew Paris [7, p. 507, no. 320]. The strength of the army marching through Moravia is unclear, as mentioned above. The Polish scholar Wacław Korta

\footnotetext{
2 “(..) ad portam Hungarie (...)” [48, p. 83].
} 
estimated that before the battle at Legnica there were about 8000 fighting men so the troops that entered Moravia must have been less numerous [24, p. 108].

Unfortunately, we cannot further support this story with Bohemian chronicles of that time since there are virtually none surviving. There is one exception though, a very short part of the Second Sequel to Cosmas, a compilation from the end of the $13^{\text {th }}$ century containing older chronicles (or, to be more precise, their extrapolations). According to the unknown Bohemian chronicler, a great fear of the Mongols spread across the kingdom as early as 1240 . The next year, the pagan Tartars (Mongols) destroyed many Christian lands. They shot dead Koloman, the brother of the king of Hungary, and depopulated his lands. Furthermore, they killed the Polish Duke Henry in a battle. This is all the information we have. There is not a line about the Tartars in Moravia. On the other hand, the chronicler had enough space to mention that a new dean of the St. Vitus Cathedral in Prague was elected and that on the $5^{\text {th }}$ of October that year there was a solar eclipse [16, p. 285]. Other pieces of information from mid-13 ${ }^{\text {th }}$-century chronicles, epistles and other documents are brief and add very little to our story, and the Asian sources hold no information about Mongols in Moravia whatsoever [36; 37]. Furthermore, there is still no definite archaeological proof of the Mongol presence in Moravia.

Even though the Mongols inflicted some damage upon the countryside, Moravia was not seriously depopulated, as some parts of the Kingdom of Hungary were, and its towns and other fortified places remained untouched [15].

$$
* * *
$$

A key event that confused even medieval chroniclers occured just 12 years afterwards, when Moravia was invaded by the king of Hungary with his armies, which included Cuman troops. The story of the Cumans is quite a well-known one and it is linked to the Mongol invasion of the west. The Cumans, a steppe people of Eurasian origin, arrived in the Kingdom of Hungary while fleeing the Mongols after they subjugated most of the Cuman lands in the winter of 1237/1238. In the troublesome period of the Mongol invasion of the Kingdom of Hungary in early 1241, Cuman leaders became victims of the angry Hungarians and the rest of their people left the country to be invited back again after the Mongols' withdrawal, to resettle the abandoned countryside [26, p. 129, 133, 138, 153, 190]. Master Roger states that 40,000 families settled in the Kingdom of Hungary and even though this number is repeated in most of the studies dealing with this subject, Hungarian scholars ended up with the rough estimate of just 70-80,000 persons (not families) $[30$, p. $157 ; 48$, p. 67]. The Cumans frequently served as light cavalry in the army of the Hungarian kings and that is how they entered Moravia in 1253.

After the death of the Duke of Austria, Frederick the Quarrelsome, in 1246, the Babenberg heritage became a big issue in central European politics. After many twists, the Austrian nobility accepted the Bohemian Prince and Margrave of Moravia Přemysl Otakar as their duke at the end of 1251. This was against the ambitions of the King of Hungary Bela IV, whose relative, Roman Danylovich, also claimed the Babenberg succession. It was mainly for this reason that the king of Hungary put together a big alliance against Přemysl Otakar and his royal father Wenceslas I. The coalition waged a full-scale attack in 1253 from several directions: Austria was invaded by Otto II, the Duke of Bavaria and his two sons; Opava was besieged by Daniel of Galicia (the father of Roman Danylovich) and the Polish Dukes Bolesław 
V the Chaste of Kraków and Władysław I of Opole and, finally, Béla IV with his troops invaded Moravia and besieged the most important Moravian city, Olomouc. The invasion eventually failed. The Bavarian troops in Austria were not very successful and after the death of Otto II in late November 1253, his sons terminated further military operations there. Daniel of Galicia, along with his Polish allies, failed to breach the firm (though still wooden) walls of Opava and they returned home. Béla IV began his campaign more successfully. He managed to defeat the Moravian troops at the ford in Přerov (Prerau), besieged Olomouc, and on the $25^{\text {th }}$ of June defeated another army trying to break the Hungarian siege. But since his allies did not manage to join him near Olomouc and his position was endangered by both Wenceslas I and his son Prremysl Otakar, Béla was forced to retreat back to Hungary without fulfilling his goals [12, p. 203-207; 20, p. 38-47; 21; 29, p. 301]. What is important for our story is the fact that this invasion was described vividly by the chroniclers and other sources, as opposed to the Mongol invasion, which barely left a mark in medieval records of that time. That was one of the reasons why these two events were later often confused.

Very influential in this respect was the Chronicle of the so-called Dalimil, a Czech rhymed chronicle from the beginning of the $14^{\text {th }}$ century. In one of the chapters, it describes the Mongol invasion, but very often it supplies wrong information. The invasion, according to Dalimil, began in 1242; the Mongols killed Henry the Bearded near Wrocław (in fact it was his son Henry II the Pious), etc. There is also some unverifiable information. For instance, that before the invasion, there were some mysterious people called the "Kartasi" who wandered all the way through central Europe to the Rhine and who were in fact Mongol spies. Another such piece of information is that the Mongols, after defeating the Polish dukes, were stopped near Kladsko (Glatz, Kłodzko). The Mongols, according to the chronicler, also spent some time around Olomouc and a Mongol prince was killed there [47, p. 313-325]. After that, the Mongols allegedly invaded Poland. Dalimil probably confused the Mongol and Cuman invasions (during the latter a battle near the besieged Olomouc really took place) and he also took up and adapted some elements of the legend of saint Hedwig of Silesia (the mother of Henry II the Pious). This confusion could be also supported by the fact that the chronicler records virtually no information about the invasion of 1253. While there is a whole chapter about the Mongols, there are just two lines that might be a vague description of the Hungarian invasion of Moravia in 1253 [47, p. 370-371, verse 82/27-28].

Another important piece of the puzzle is the late $14^{\text {th }}$-century chronicle usually called the chronicle of Příbík Pulkava of Radenín. It was one of the chronicles issued - and perhaps even supervised - by the Holy Roman Emperor Charles IV. This Latin chronicle, extant in several different variants that emerged from 1364 to 1374, was also translated into Czech and German and was very popular at that time. The first variant of the chronicle records nothing about the Mongol invasion of 1241 but supplies some previously-unknown details about the invasion of the king of Hungary with his Cumans, dating it incorrectly to 1254 . To paraphrase the account briefly: Tartars, who had been pillaging the Kingdom of Hungary for several years, attacked and devastated Moravia and caused a massacre near Olomouc, 
but from that city a noblemen from the house of Sternberg - the Captain of the city at the time - made a foray into enemy lines and mortally wounded the Tartar leader. The Tartars then retreated back to Hungary. That nobleman was then given some lands near Olomouc and founded a new castle there called Sternberg [28, p. $143-144 ; 38$, p. 360-361]. The last variant rectified the previous mistakes and correctly - yet very briefly - described the events of 1241 and 1253. In this last variant, the Tartars are correctly distinguished from the Cumans, but it lacks any information about the noblemen from the house of Sternberg whatsoever [28, p. 138,$144 ; 38$, p. 357,361$]$.

It is important here that the first variant of the chronicle brought forward the motif of the hero of the house of Sternberg for the first time. This house ranks among the oldest and most important noble houses in Bohemia and Moravia. At the time of both the Mongol and the Cuman invasions, Zdeslav of Sternberg, the son of Diviš, was the head of the house. The mid- $13^{\text {th }}$-century sources, however, never mention his involvement with any of the invaders and we know for sure that he was not the Captain of Olomouc in 1253 [21, p. 282]. On the other hand, he had some possessions in Moravia and he founded the castle and the small town of New Sternberg there (mentioned for the first time in 1269) [35, p. 32-40]. Moreover, on the $5^{\text {th }}$ of August 1253, just few days after the end of the siege, he was in Olomouc as an entourage of the Margrave of Moravia and future King Přemysl Otakar [7, p. 481, no. 287]. Why the first variant of the chronicle mentioned an unnamed member of this noble house is unclear. Perhaps he really helped to hold Olomouc and perhaps the author only wanted to flatter Albrecht of Sternberg, one of the closest advisors to the Emperor, the Bishop of Schwerin (1356-1363) and since 1364 the Bishop of Litomyšl (Leitomischl) who began his career as the Dean of the Olomouc Chapter some years earlier [35, p. 85-101].

All of those chronicles were only available as manuscripts, which hugely limited the number of potential readers. A big change came after the invention and spread of the printing press. Without exaggeration, it is fair to say that the most important and widespread treatise about the history of the Kingdom of Bohemia until the first half of the $19^{\text {th }}$ century was the Kronika česká (The Bohemian chronicle) by Václav Hájek of Libočany, published in 1541 in Czech. Although Václav Hájek used an admirable number of sources, he also made a lot of mistakes, and in some places, he added many of his own ideas, which then circulated as facts for centuries. His description of the Mongol invasion is quite overstated. The Mongol forces, according to Hájek, which were about half a million strong, had been harassing Poland until 1243 when the King of Bohemia Wenceslas I decided to help Poland. The invaders were overawed by his forces and moved quickly through Moravia - which they plundered hard - to Hungary to join their comrades there $\left[17\right.$, p. CCXXXI - CCXXXII $\left.^{\mathrm{v}}\right]$. Around the year 1253, Hájek wrote that the king of Hungary had invaded Moravia with an army of Cumans and Tartars. The enemies then pillaged Moravia, except for the fortified places, and eventually decided to take Olomouc. The Captain of the city was Jaroslav of Sternberg who attacked the enemy and, after a fierce fight, cut-off the hand of the foreign leader Belzait. The enemy then withdrew and Belzait died of his wounds en route. King Wenceslaus then gave Jaroslav some lands near Olomouc, the nobleman founded the New Sternberg there and until the end of his days he was also the Captain of the whole of Moravia [17, p. CCXXXVII ${ }^{\mathrm{r}}-\mathrm{CCXXXVIII}^{\mathrm{r}}$ ]. 
Hájek's account is very important, because he added the name of the previously unknown hero. Because of the importance of his book, Jaroslav shortly afterwards became a heroic ancestor to his family and later on even a national hero. The name Jaroslav is most probably as fictional as the whole victory at Olomouc (the Moravian and Bohemian forces were actually defeated there). It was Zdeslav of Sternberg who lived around the time of the clash. On the other hand, one of Zdeslav's sons was really called Jaroslav, but it is highly improbable he was old enough to lead major forces and, moreover, his ancestral line was involved in Bohemia rather than Moravia [35, p. 292]. It is unclear whether Hájek invented the events or whether he just collected existing stories, but as early as 1550 there is written proof that Jaroslav was perceived as a hero who, in 1252 (sic!), saved Olomouc from the pagan Tartars brought there by Béla IV, the King of Hungary [14, p. A4b-B].

So far, we have observed how the Mongol invasion was often confused with the Cuman invasion and how the defeat near Olomouc suddenly became a victory thanks to Jaroslav of Sternberg. It would be very lengthy and, perhaps, even useless to search for all the other mentions of the Mongol and Cuman invasions of Moravia in other documents, but there is still one piece missing. That is, how Jaroslav became a hero defeating not the Cumans at Olomouc in 1253, but the Mongols in 1241. As mentioned earlier, the events of 1241 and 1253 were often confused, and it is not surprising, then, that we can find this missing link as early as 1552, when Johannes Dubravius (Jan Skála z Doubravky), an educated humanist, writer and the Bishop of Olomouc at the time, published his Latin chronicle Historiae Regni Boiemiae. In his book he depicted the Mongol invasion of Moravia of 1241 in vivid colours. The leader of the Mongol troops, Peta, was defeated in front of Olomouc by its Captain who was from the house of Sternberg. This unnamed hero was then given some lands by the king and became Captain of the whole of Moravia $\left[13\right.$, p. $\left.\mathrm{C}^{\mathrm{r}}-\mathrm{CI}^{\mathrm{r}}\right]$. Even though the hero here remains nameless, his family ancestry is stressed several times. Combined with Hájek's information, Jaroslav of Sternberg, the hero who defeated the Mongols at Olomouc in 1241, was born. Just one example of this approach dates to the year 1677, when Tomáš Pešina of Čechorod published a Latin book about military conflicts in Moravia called Mars Moravicus. There, he had no doubt that the leader of the 8,000 brave knights who attacked the Mongols from the besieged Olomouc in 1241 was Jaroslav of Sternberg, who personally cut off the arm of their leader Peta and thus averted the whole invading army [34, p. 344-348].

The motif of the heroic Jaroslav of Sternberg defeating the Tartars at Olomouc in 1241 soon became part of the ancestral myth of the still-very-important noble house of Sternberg, who used it as a part of their family image. Jaroslav's deeds even became part of the legend associated with their coat of arms in the $18^{\text {th }}$ century $[44$, p. $281-282,311]$. It is no wonder that they frequently commissioned paintings depicting their fictional ancestor defeating the Mongols for their residences [35, p. 253].

$$
* * *
$$

The Tartar myth was transformed once again in the second half of the $17^{\text {th }}$ century into a story surrounded by miracles. To survey this phase of the story thor- 
oughly would be a subject for a completely different study. Here I will just stress some important moments. The Kingdom of Bohemia was inhabited by both Catholics and Protestants before 1620, but this changed after the outbreak of the Thirty Years' War, which eventually led to a strict recatholization of the Kingdom. This process was also connected to baroque culture and new types of religious spirituality characterised for instance by pilgrimages to the shrines of local cults.

There was also another factor that made the events of 1241 current again: the Ottoman threat, which was even closer to the Moravian border after 1526, when the King of Hungary and Bohemia Louis II was killed at the battle of Mohács. This threat materialized during the Austro-Turkish War of 1663-64. The Ottoman forces were eventually defeated at the battle of Saint Gotthard on the $1^{\text {st }}$ August 1664 but before that, Moravia witnessed three raids by Ottoman light troops (consisting at least partially of Crimean Tatars) between $4^{\text {th }}$ September and $7^{\text {th }}$ October 1663 . This was more a series of skirmishes than a full-scale attack, but even though no fortified place had fallen to the enemy, the Moravian countryside was heavily plundered, many of the people were killed and many were taken prisoner. The rumours about the incoming Tatars caused panic in Moravia even before the raids began, but the trauma of the actual presence of these oriental pagan warriors echoed among the Moravians for decades. It is no coincidence that very shortly after these raids, three miraculous events connected to the Mongol invasion of 1241 were invented [9, p. 196-207; 18, p. 118-119; 39; 49, p. 119-120].

The first - and the most important - setting of these miracles was a hill called Hostýn. Its importance had been growing rapidly since the mid-1600s when it became part of the dominion of Count Johann of Rottal, the Captain of Moravia and a zealous Catholic, who was actively involved in the process of recatholization. During his lifetime, Hostýn became a place well-liked by Catholic pilgrims. Soon after the events of 1663, the Hostýn miracle was invented, which goes as follows: the besieged Moravians were defending themselves against the Tartars in 1241 on the Hostýn hill and they were suffering from unbearable thirst. They prayed and the Virgin Mary not only gave them water that miraculously sprang out of the hill, but also attacked the invaders with lightning and they fled. This legend is clearly fictional. Since 1666, when it was written down for the first time, its details changed several times to be definitely fixed down in the aforementioned form in 1700 by František Beckovský [2, p. 399]. Hostýn was a very popular place of pilgrimage until the end of the $18^{\text {th }}$ century, when all pilgrimages were banned [31, p. 281-312].

Štramberk and the hill Kotouč became another centre of pilgrimages connected to the fictional defence against the Tartars in 1241. The story here is very similar to Hostýn. Štramberk was given to the Jesuit Convict in Olomouc in the first half of the $17^{\text {th }}$ century. The Society of Jesus was for some time a very influential religious order strongly connected in Bohemia and Moravia with both recatholization and education. The new owners of Štramberk supported pilgrimages and it is no wonder that a legend referring to the Tartar invasion of 1241 was soon invented (written down for the first time in the 1660s). The legend says that during the invasion, people from Štramberk took refuge on the top of a nearby hill called Kotouč. The Tartars surrounded the hill and the situation was seemingly desperate. The defenders then prayed to God in the evening before the Feast of the Ascension and he sent a pouring rain down upon the infidels and the roaring waters scared them so much that they fled. This legend is known in several different ver- 
sions. Most popular today is the one in which the people of Stramberk covertly ruptured the dams of the nearby ponds and the water destroyed the Tartar camp and killed many of them. The people of Stramberk then found nine sacks filled with ears cut off the heads of the defeated Christians in the flooded camp (this motif is clearly adopted from Długosz). A very interesting version comes from the 1720s, when a Štramberk magistrate was describing the miracle. In their story, the enemies were not the Tartars, but the Hussites (Calixtines), and the year was not 1241, but 1356 (sic!) [4, p. 63]. This only proves that the Tartar myth was still very young at that time and not known to - or accepted by - everyone $[27$, p. $7 ; 31$, p. 288; 32, p. 75].

Another place that became the setting of a Tartar myth was Olomouc. Very similarly to the cases of Hostýn and Štramberk, the events near Olomouc were eventually transformed into a religious miracle, this time connected to the Body of Christ. The Olomouc miracle emerged from several different roots. The Sternberg myth (including Jaroslav) was already established and well promoted, for instance in churches established or supported by the Sternberg family in Olomouc. Furthermore, the Jesuits founded a university in Olomouc in 1573 and part of its Convent was the Corpus Christi Chapel. Once again, not long after the Tatars invaded Moravia in 1663, the Olomouc legend was written down for the first time. According to it, Olomouc was besieged by the Tartars in 1241. The Captain of the city, Jaroslav of Sternberg, attended a Mass before attacking the enemy. After the communion, five pieces of the sacramental bread were left over and they were wrapped up and carried to the battle on the back of a donkey. With the help of God, Jaroslav defeated the enemy, personally cutting-off the hand of their leader Peta, who later died of his wounds, and the rest of the invaders fled to Hungary. After the battle, the priest who unwrapped the sacramental bread found out that it turned into the real Body of Christ. He put it back on the donkey and the animal carried the sacred cargo straight to the Corpus Christi Chapel in Olomouc completely on its own, where it has been kept since then. Jaroslav then founded the church of the Virgin Marry in Olomouc and was generously rewarded by the king. The Corpus Christi Chapel in Olomouc obviously could not be the place where the poor animal carried its burden after the battle, since in the $13^{\text {th }}$ century, the location of the future Jesuit Convent was part of the Jewish quarter and remained so until 1454. Regardless of the obvious flaws, the legend became very popular, with its centre in the Corpus Christi Chapel, which was rebuilt in the 1720s and marvellously decorated by Jan Kryštof Handke in 1727-28. The early $18^{\text {th }}$-century frescoes inside depict the legend with the Mongols portrayed as Ottoman Turks. The decoration of the older Corpus Christi Church, however, also depicted this legend, including the altarpiece, which was often copied as a copperplate prints in the early 1700s [2, p. 398; 32].

$$
\text { * * * }
$$

As the $18^{\text {th }}$ century was drew to a close, the era of religious pilgrimages and miracles was slowly coming to an end. This process was hastened during the reign of the enlightened Holy Roman Emperor and ruler of the Habsburg lands, Joseph II (1780-1790), who was very active in the process of secularizing of his lands. Pilgrimages were banned and the Tartar myth (in its religious form) was slowly fading away. But our story has yet another twist. In 1817, Václav Hanka "found" a 
fragment of a manuscript in a church in Dvůr Králové nad Labem (Königinhof an der Elbe). It was a sensation. This fragment, written in Czech, supposedly originated in the $13^{\text {th }}$ century and as such, it would have been the oldest surviving piece of literature in the Czech language. This fact boosted the self-confidence of the still young Czech National Revival. The key part of this fragment, later called the Manuscript of Dvůr Králové (Königinhofer Handschrift), was the poem "Jaroslav", exalting Jaroslav of Sternberg and his heroic victory against the Tartars in 1241. It also mentioned the events in Hostýn. There was only one problem. This fragment (and the one found a year later, the Manuscript of Zelená Hora, dating to the turn of the $10^{\text {th }}$ century) was an elaborate forgery by Václav Hanka, which was definitely proved, after fierce discussions, only at the end of the $19^{\text {th }}$ century [41].

This "ancient" Czech poem about the epic victory over the Asian invaders reinvented the myth once again, only this time it was used to document the historical importance of the Czech nation. A perfect time to commemorate the brave ancestors came at the $600^{\text {th }}$ anniversary of the event in 1841. Many celebrations took place (especially in Hostýn and Olomouc) but it was also the time to write down a new history of the Mongol invasion. The historian František Palacký (also called the father of the nation) prepared a lecture on the issue and published it in German in 1842 [33]. This short book is a nice example of rigorous critical historiography with just one flaw: Palacký believed in the authenticity of the Manuscript of Dvưr Králové.

In Moravia, Alois Vojtěch Šembera edited an almanac containing articles on the history of the Mongol invasion, as well as some poems on the topic [43]. This almanac contains a treatise by Antonín Boček about the identification of the hero who defeated the Mongols at Olomouc [3]. Antonín Boček was the official Moravian historian and he also edited the oldest Moravian sources (Codex diplomaticus et epistolaris Moraviae). Unlike Palacký, he had his doubts about the Manuscript of Dvưr Králové nad Labem and according to him, the true hero was not Jaroslav, but Zdislav of Sternberg. That was a smack in the face of Palacký, since he had, as a young man, been a family archivist to the Sternberg family, and he also compiled their genealogy. During their efforts to critically describe the true events of 1241, Boček and Palacký dealt with the problem I have mentioned above: there are frustratingly few authentic sources documenting the event. Boček solved this setback in a very special way. He simply added non-existent charters to his edition of the Moravian sources, seemingly proving the devastating impact of the invasion. It is no surprise that the third volume of his Codex diplomaticus et epistolaris Moraviae, covering the years 1241-1267, and containing the bulk of these forgeries was published in Olomouc in 1841 [7]. Suddenly, there was proof that the Mongols destroyed or damaged the monasteries Hradisko u Olomouce, Rajhrad, Doubravník and the cities Brno, Bruntál, Benešov, Litovel, Jevíčko and Uničov. In 1855 , these forged documents were included in the first volume of the CzechMoravian sourcebook (Regesta) and these were also the misleading sources Peter Jackson used [23, p. 68; 40].

After its $600^{\text {th }}$ anniversary, the Mongol myth began trending once again. The Hostýn Church was rebuilt and became an important symbol of the nation and its past. But not even this revival lasted forever. The importance of Hostýn was overshadowed by Velehrad and by the memory of the saints Cyril and Methodius on the millennial anniversaries in 1863 and 1885. Moreover, the fragments of the 
Manuscripts of Dvůr Králové and Zelená Hora were proven to be forgeries in the 1880 s, as well as Boček's forgeries some years later [4; 42]. The story of the national hero became a rather awkward reminder of the forged history of the nation and for some it even became a joke - as it was for the famous writer Jaroslav Hašek in the 1920s [19].

\section{REFERENCES}

1. Annales s. Pantaleonis Coloniensis. Ed. H. Cardauns. Monumenta Germaniae Historica. Scriptores, vol. XXII. Ed. G.H. Pertz. Hannoverae, Impensis Bibliopolii Avlici Hahniani, 1872, pp. 529-547. (In Latin)

2. Beckovský J.F. Poselkyně Starých Přjběhưv Cžeských. Staré Město Pražské, Jan Karel Geřábek, 1700. 1040 p. (In Czech)

3. Boček A. O wjtězi nad Mongoly. Wpád Mongolu do Morawy. Ed. A.W. Šembera. Holomouc, Aloysius Škarnicl, 1841, pp. 55-64. (In Czech)

4. Bretholz B. Die Tataren in Mähren und die moderne mährische Urkundenfälschung. Zeitschrift des Vereines für die Geschichte Mährens und Schlesiens, 1897, vol. 1, pp. 1-65. (In German)

5. Buell P.D. Historical Dictionary of the Mongol World Empire. Lanham (Md.), Scarecrow, 2003. 333 p.

6. Chambers J. The Devil's Horsemen. The Mongol Invasion of Europe. London, Weidenfeld and Nicolson, 1979. 190 p.

7. Codex diplomaticus et epistolaris Moraviae, vol. III. Ed. A. Boček. Olomucii, Aloysius Skarnitzl, 1841. 412 p. (In Latin)

8. Codex diplomaticus et epistolaris Regni Bohemiae, vol. IV, file 1. Eds. J. Šebánek, S. Dušková. Pragae, Acad. scient. Bohemoslovenicae, 1962. 589 p. (In Latin)

9. Čornejová I. et al. Velké dějiny zemí Koruny české, VIII. Praha-Litomyšl, Ladislav Horáček - Paseka, 2008. 711 p. (In Czech)

10. de Hartog L. Genghis Khan. Conqueror of the World. London-New York, Tauris Parke Paperbacks, 2004. 230 p. (In English)

11. Dejmek J. Děpoltici. (K mocenskému postavení jedné vedlejší větve Přemyslovců). Mediaevalia Historica Bohemica, 1991, vol. 1, pp. 89-144. (In Czech)

12. Dopsch H., Brunner K., Weltin M. Österreichische Geschichte 1122-1278. Die Länder und das Reich. Der Ostalpenraum im Hochmittelalter. Wien, Ueberreuter, 1999. 620 p. (In German)

13. Dubravius J. Historiae Regni Boiemiae. Prostějov, Jan Günther, 1552. 428 p. (In Latin)

14. Ennio Glatovinus S. Breve Encomion Olomvcii metropolis in Moraviae Marchionatu. Prostějov, Jan Günther, 1550. 16 p. (In Latin)

15. Font M. The Crises of Medieval Society: The Mongol Invasion in Eastern and Central Europe. Ukrajina: kul'turna spaď̌čyna, nacional'na svidomist', deržavnist', 2011, vol. 20, pp. 691-698.

16. Fontes rerum Bohemicarum, vol. II. Ed. J. Emler. Praha, Museum Království českého, 1874. 570 p. (In Czech and Latin)

17. Hájek z Libočan V. Kronyka Czeská. Menší Město pražské, Jan Severýn - Ondřej Kubeš, 1541. 474 p. (In old Czech)

18. Hammer J. Geschichte des Osmanischen Reiches. Sechster Band. Pest, C.A. Hartleben's Verlage, 1830. 770 p. (In German)

19. Hašek J. The Good Soldier Švejk and His Fortunes in the World War. Transl. Cecil Parrott. London, David Campbell Publishers, 2000. 800 p. 
20. Hoensch J.K. Přemysl Otakar II. von Böhmen: der goldene König. Graz, Verlag Styria, 1989. 303 p. (In German)

21. Hosák L. Uhersko-kumánský vpád na Moravu r. 1253. Acta Universitatis Palackianae Olomucensis. Historica, 1960, vol. 1, pp. 279-284. (In Czech)

22. Ioannis Dlugossi Annales seu cronicae incliti Regni Poloniae. Liber 7/8. Eds. Z. Kozłowska-Budkowa et al. Varsaviae, Państ. Wydaw. Naukowe, 1975. 431 p. (In Latin)

23. Jackson P. The Mongols and the West: 1221-1410. London, Routledge, 2005. $448 \mathrm{p}$.

24. Korta W. Najazd Mongołów na Polskę i jego legnicki epilog. Katowice, Śląski Instytut Naukowy, 1983. 155 p. (In Polish)

25. Korta W. Problemy bitwy legnickiej i stan badań. Bitwa Legincka: Historia $i$ tradycja. Ed. W. Korta. Wrocław-Warszawa, Oficyna Wydawnicza Volumen, 1994, pp. 7 33. (In Polish)

26. Kosztolnyik Z.J. Hungary in the thirteenth century. New York, East European Monographs, 1996. 510 p.

27. Králík O. Historická skutečnost a postupná mytizace mongolského vpádu na Moravu roku 1241. Př́spěvek $k$ ideologii předbřeznové Moravy. Olomouc, Socialistická akademie v Olomouci, 1969. 47 p. (In Czech)

28. Kronika Pulkavova. Ed. J. Emler. Fontes rerum Bohemicarum, vol. V. Praha, Edv. Valečka, 1893, pp. 1-326. (In Latin)

29. Lechner K. Die Babenberger. Margrafen un Herzoge von Österreich 976-1246. Wien, Böhlau, 1976. 478 p. (In German)

30. Lyublyanovics K. The Cumans in Medieval Hungary and the Question of Ethnicity. Annual of Medieval Studies at CEU. Budapest, Central European University, Department of Medieval Studies, 2011, vol. 17, pp. 153-169.

31. Maur E. Pamět' hor. Šumava, Říp, Blaník, Hostýn, Radhošt'. Praha, Havran, 2006. 375 p. (In Czech)

32. Mlčák L., Mlčáková K. Mědirytiny $\mathrm{k}$ barokní legendě o zázračném vítězství Jaroslava ze Šternberka nad Tatary u Olomouce. Středni Morava. Olomouc, Memoria, 2001, vol. 7, pp. 65-77. (In Czech)

33. Palacky F. Der Mongolen Einfall im Jahre 1241. Prag, Kronberger und Řiwnač, 1842. 38 p. (In German)

34. Pešina z Čechorodu T. Mars Moravicus. Praha, Jan Arnolt z Dobroslavína, 1677. 1001 p. (In Latin)

35. Pokluda Z. Moravští Šternberkové. Panský rod rozprostřený od Jeseníků ke Karpatiom. Praha, Nakladatelství Lidové noviny, 2012. 353 p. (In Czech)

36. Pokora T. Mongolský vpád do Slezska a na Moravu v roce 1241. (Dokončení). Sborník Vlastivědné společnosti muzejní v Olomouci. Ostrava, Profil, 1974-1976, vol. 63 (4), pp. 98-110. (In Czech)

37. Pokora T. Mongolský vpád do Slezska a na Moravu v roce 1241. Několik poznámek na základě evropských a čínských středověkých pramenů. Sborník Vlastivédné společnosti muzejní v Olomouci. Ostrava, Profil, 1973, vol. 62 (3), pp. 172-183. (In Czech)

38. Přibíka z Radenína, řečeného Pulkava, Kronika česká. Ed. M. Bláhová et al. Kroniky doby Karla IV. Praha, Svoboda, 1987, pp. 269-444. (In Czech)

39. Procházka J. Válka s Turky 1663-1664, "bídný” mír a osmanští “špehaři”. Sborník prací Pedagogické fakulty Masarykovy univerzity v Brně. Řada společenských věd. Brno, Masarykova univerzita, 1996, vol. 13, pp. 25-33. (In Czech)

40. Regesta diplomatica nec non epistolaria Bohemiae et Moraviae, vol. I. Ed. K.J. Erben. Pragae, s.n., 1855. 812 p. (In Latin)

41. Rychterová P. The Manuscripts of Grünberg and Königinhof: Romantic Lies about the Glorious Past of the Czech Nation. Manufacturing a Past for the Present: Forgery and Authenticity in Medievalist Texts and Objects in nineteenth-century Europe. Eds. J.M. Bak et al. Leiden-Boston (MA), Brill, 2015, pp. 3-30. 
42. Šebánek J. Moderní padělky v moravském diplomatáři Bočkově do roku 1306. Časopis Matice moravské. Brně, Nákladem Matice moravské, 1936, vol. 60, pp. 27-84, 455-499. (In Czech)

43. Šembera A.W. (ed.) Wpád Mongoli̊ do Morawy. Holomouc, Aloysius Škarnicl, 1841. 108 p. (In Czech)

44. Šimůnek R. Reprezentace české středověké šlechty. Praha, Argo, 2013. 474 p. (In Czech)

45. Sinor D. The Mongols in the West. Journal of Asian History. Wiesbaden, Otto Harrassowitz, 1999, vol. 33, no. 1, pp. 1-44.

46. Sodnomyn C., Cenoma E. Podbój Polski przez wojska Batu-Chana. Bitwa Legincka: Historia i tradycja. Ed. W. Korta. Wrocław-Warszawa, Oficyna Wydawnicza Volumen, 1994, pp. 84-89. (In Polish)

47. Staročeská kronika tak řčeného Dalimila: vydání textu a veškerého textového materiálu, vol. 2. Eds. J. Daňhelka et al. Praha, Academia, 1988. 608 p. (In old Czech)

48. Tatársky vpád: historické rozprávanie o strašných udalostiach, ktoré priniesli obyvatelom Uhorského královstva vela utrpenia a celú krajinu priviedli na pokraj skazy. Eds. R. Marsina, M. Marek. Budmerice, Vydavatel'stvo Rak, 2008. 167 p. (In Slovak and Latin)

49. Válka J. Dějiny Moravy 2. Morava reformace, renesance a baroka. Brno, Muzejní a vlastivědná společnost, 1996. 275 p. (In Czech)

About the author: Tomáš Somer - Ph.D. (History), Senior Lecturer, Department of History of the Faculty of Arts of the Palacký University Olomouc, ORCID: https://orcid.org/0000-0002-8847-1768 (tř. Svobody 671/8, 77900 Olomouc, Czech Republic). E-mail: tomas.somer@upol.cz

\title{
ФАЛЬСИФИКАЦИЯ ПРОШЛОГО: ФАКТЫ И МИФЫ МОНГОЛЬСКОГО ВТОРЖЕНИЯ В МОРАВИЮ В 1241 ГОДУ
}

\author{
Томаш Сомер \\ Университет Палачкого в Оломоуце \\ Оломоуи, Чехия \\ tomas.somer@upol.cz
}

\begin{abstract}
Цель исследования: данное исследование преследует две цели. Во-первых, представить обзор событий, связанных с монгольским вторжением в Моравию весной 1241 года. Во-вторых, рассмотреть, как история менялась в течение последующих столетий. «Монгольский миф» вскоре потерял связь с реальностью и несколько раз преображался в совершенно другую историю. В данном исследовании показано когда, почему и как эта история менялась.

Материаль исследования поэтому разнообразны. Первая часть исследования основывается на источниках XIII века (грамоты, послания, хроники) центрально-
\end{abstract}


европейского происхождения. Во второй части будут рассмотрены более поздние средневековые хроники, а также исторические трактаты раннего Нового времени. Эти работы повлияли на восприятие (и форму) истории как на родине, так и за рубежом, поскольку многие из них были доступны на разных языках.

Таким образом, результаты и новизна исследования являются двоякими. Поскольку «монгольский миф» стал предметом фальсификаций XIX века, многие ученые были введены ими в заблуждение, так что поддельные документы представляются в качестве достоверных источников даже известными современными учеными. В результате, фактические события 1241 года подверглись драматическим изменениям. Вторжение, представлявшееся иногда как катастрофа, в действиительности было кратким прохождением монгольских войск через моравскую территорию. Позже хронисты спутали это событие с венгерским вторжением в Моравию 1253 года. Вскоре была изобретена вымышленная победа при Оломоуце, позже был добавлен воображаемый герой (Ярослав из Штернберга), и история во второй половине XVII века преобразилась в религиозное чудо, чтобы стать важнейшей составляющей подделок XIX века, утрировавших славу национального прошлого при помощи изобретения никогда не существовавших источников.

Ключевье слова: Монгольская империя, Моравия, куманы, 1241 год, историография

Для цитирования: Somer T. Forging the Past: Facts and Myths behind the Mongol Invasion of Moravia in 1241 // Золотоордынское обозрение. 2018. Т. 6, № 2. С. 238 251. DOI: $10.22378 / 2313-6197.2018-6-2.238-251$

Сведения об авторе: Томаш Сомер - Ph.D. (история), доцент, кафедра истории гуманитарного факультета университета Палацкого в Оломоуце, ORCID: https://orcid.org/0000-0002-8847-1768 (tř. Svobody 671/8, 77900 Olomouc, Czech Republic). E-mail: tomas.somer@upol.cz 